Vol 1. No 1. Februari 2017

\title{
KOLEKSI DNA DAN KONFIRMASI MARKA ETH10 PENGKODE SIFAT PERTUMBUHAN PADA SAPI PASUNDAN
}

\author{
Heny Utami Ningsih"1 ${ }^{*}$, Tatag Bagus Putra Prakarsa. ${ }^{1}$, Endang Tri Margawati, ${ }^{2}$ \\ 1Prodi Biologi, Fakultas Sains dan Teknologi, UIN Sunan Ampel Surabaya, \\ ${ }^{2}$ Laboratorium Genetika Hewan, Puslit Bioteknologi, Lembaga Ilmu Pengetahuan Indonesia \\ (LIPI), Cibinong Bogor. \\ *Email: Henyutami07@gmail.com
}

\begin{abstract}
ABSTRAK
Sapi Pasundan secara genetik merupakan generasi dari tetua yang mengalami tekanan inbreeding dari program grading up sapi Ongole dan program grading up sapi Jawa dengan sapi Madura dan sapi Bali. Sifat pertumbuhan merupakan salah satu sifat penting bernilai ekonomis. Salah satu kandidat marka genetik pengkode sifat pertumbuhan yaitu marka mikrosatelit ETH10. Tujuan dari penelitian ini yaitu memahami prosedur konfirmasi marka ETH10 pengkode sifat pertumbuhan pada sapi Pasundan. Sebanyak tiga (3) sampel darah sapi Pasundan $(619,626$, dan 602) diambil dari vena caudalis yang digunakan dalam isolasi DNA dengan metode garam pekat. DNA yang dikoleksi kemudian dikuantifikasi menggunakan spektrofotometer untuk mengetahui konsentrasi DNA ( $\lambda 260)$ dan kemurnian DNA ( $\lambda 260 / \lambda 280)$. Amplifikasi marka ETH10 menggunakan metode Polymerase Chain Reaction (PCR) dengan suhu annealing 60oC dan 35 siklus. Produk PCR gen (fragment) ETH10 divisualisasi pada Gel Agarose 1,5\%. Hasil isolasi DNA diperoleh dengan rata-rata konsentrasi DNA sebesar $116,37 \pm 63,37 \mathrm{ng} / \mu \mathrm{l}$ dan kemurnian DNA sebesar 1,72 $\pm 0,035$. Selanjutnya hasil Amplifikasi marka DNA ETH10 pada sapi Pasundan menunjukkan ukuran fragment sebesar 212-224 pb pada ke tiga sampel. Kesimpulan dari penelitian ini yaitu telah terkonfirmasinya marka ETH10 yang berhubungan dengan sifat pertumbuhan pada sampel sapi Pasundan. Hasil tersebut dapat digunakan sebagai informasi awal dalam analisis genetik sapi Pasundan.
\end{abstract}

Kata Kunci: Koleksi DNA, Konfirmasi, Marka ETH10, Pertumbuhan, Sapi Pasundan

\section{PENDAHULUAN}

Di Indonesia terdapat beberapa sapi lokal yang memiliki daya adaptasi yang tinggi terhadap pakan yang berkualitas rendah, sistem pemeliharaan ekstensif dan memiliki daya tahan terhadap penyakit ektoparasit. Keunggulan yang dimiliki oleh sapi lokal ini perlu dipertahankan sebagai plasma nutfah Indonesia dan perlu dikembangkan sebagai kekayaan genetik yang dimiliki Indonesia. Terdapat banyak sapi lokal seperti sapi Bali, sapi Aceh, sapi Madura, sapi Ongole, sapi Peranakan Ongole, sapi 
Pesisir, dan sapi Pasundan. Diantara sapisapi lokal di Indonesia, Sapi Pasundan mempunyai potensi yang belum dipelajari keunggulannya secara molekuler.

Sapi Pasundan merupakan sapi lokal yang berkembang di masyarakat buffer zone hutan sepanjang wilayah Priangan Utara (Kabupaten Kuningan, Majalengka, Sumedang, Indramayu, Subang, Purwakarta, dan Ciamis) dan juga di wilayah Pesisir Selatan Jawa Barat, antara lain Pangandaran, Tasikmalaya, Garut, Cianjur, dan Sukabumi (Dinas Peternakan Provinsi Jawa Barat, 2014).

Sapi Pasundan ditetapkan sebagai rumpun pada tahun 2014, sapi Pasundan dan sapi lain mempunyai karakteristik yang berbeda-beda. Perbedaan karakteristik tersebut salah satunya disebabkan karena adanya diversitas genetik, yang dimungkinkan oleh adanya program-program introduksi sapi impor yang dilakukan pemerintah (Johari et al., 2007).

Program peningkatan mutu genetik sapi lokal khususnya sapi Pasundan memiliki arti yang sangat strategis, yaitu dalam rangka mengurangi ketergantungan akan sapi (bibit) impor yang jelas akan berdampak pada terkurasnya devisa negara. Terobosan baru dalam rangka mempercepat proses peningkatan mutu genetik ternak adalah dengan teknologi rekayasa DNA (teknologi mikroinjeksi DNA, sidik jari DNA, Marker Assisted Selection (Penanada molekular) dan lain-lain). Melalui teknologi ini maka interval generasi dapat diperpendek dan intensitas seleksi dapat ditingkatkan sehingga proses perbaikan mutu genetik dapat berjalan lebih cepat (Maskur et al., 2005)

Perkembangan sejumlah penanda molekular (DNA Marker) dewasa ini telah memungkinkan untuk melakukan identifikasi terhadap perubahan genetik yang terjadi dalam suatu persilangan serta hubungannya dengan perubahan sifat kuantitatif dan sifat kualitatif ternak. Selain itu, penanda molekuler juga dapat digunakan untuk membedakan antara suatu ras ternak dengan lainya terutama dalam kaitannya dengan upaya pelestarian dan menjaga kemurnian dari ras tersebut. Salah satu penanda molekular (DNA marker) yang sangat populer dewasa ini adalah mikrosatelit.

Pada saat ini marker mikrosatelit banyak digunakan sebagai penanda molekular untuk mendukung efektifitas pemuliaan ternak, penetapan asal-usul keturunan, penggalian sumber-sumber genetik dan menjadi penanda molekuler 
penting dalam analisis genetik pada beberapa bangsa sapi Ciampolini et al., 1995), Mikrosatelit telah diidentifikasi baik di daerah coding dan non-coding dari genom dan telah digunakan untuk mendeteksi Quantitative Trait Loci (QTL) (Sellner et al., 2007).

Salah satu penanda molekuler (DNA marker) adalah ETH 10. Marker mikrosatelit ETH 10 merupakan salah satu marker yang sering digunakan dalam analisis genetik pada sapi yang berhubungan dengan sifat pertumbuhan. Menurut Farber dan Medrano (2003) melaporkan bahwa ETH10 terlibat dalam signaling GH (Growth Hormone), yang mengatur pertumbuhan tulang postnatal dan otot dan metabolisme lemak pada mamalia (Zhu et al., 2001). Marka ETH10 juga sangat terkait dengan marbling pada sapi Wagyu (Barendse, 2002) dan digunakan untuk mendeteksi QTL untuk sifat pertumbuhan pada sapi persilangan Angus x Brahman (Kim et al., 2003).

Berdasarkan uraian tersebut, penelitian ini dilakukan untuk mengkonfirmasi keberadaan Marka ETH10 pada lokus mikrosatelit dalam hubungannya dengan perubahan sifat pertumbuhan pada sapi Pasundan. Hal tersebut dikarenakan informasi genetik tentang sapi Pasundan masih belum banyak di eksplor. Selain itu, FAO sebagai badan dunia sudah menganjurkan bahwa sedapat mungkin sumber daya genetik ternak lokal harus dipertahankan. Penanda genetik mikrosatelit dapat memberikan informasi informasi penting sehingga dapat dibuat keputusan mengenai konservasi pada ternak sapi (Sunnucks, 2000; Sodhi et al., 2006).

\section{METODE}

Penelitian ini dilakukan di Laboratorium Genetika Molekuler Hewan, Pusat Penelitian Bioteknologi, Lembaga Ilmu Pengetahuan Indonesia, Cibinong Science Center (CSC-LIPI) yang terletak di Jalan Raya Bogor Km. 46 Cibinong, Kabupaten Bogor- Jawa Barat, 16911 tanggal 16 Januari-16 Februari 2015.

Alat yang digunakan antara lain vacutainer yang mengandung K3EDTA, Holder, kapas, alkohol 70\%, jarum 21G, ice box, tabung falcon plastik $15 \mathrm{~mL}$, Mikropipet P1000+tips P1000, tisu, spidol marker, sentrifuge (Hermle Z 300 $\mathrm{K})$, Beaker glass, Shaker Inkubator $37^{\circ} \mathrm{C}$ (Forma incubated benchtop thermo scientific), baki plastik, lakban hitam, pipet pasteur modifikasi (pancigan), shaker (suhu ruang), mikrotubes $1.5 \mathrm{~mL}$, spidol, kertas label, parafilm, beaker glass, tabung reaksi $50 \mathrm{~mL}$, GeneQuant Spectro UV-Vis, Mikropipet P10+tips P10, dan 
kuvet 50, Amplifikasi DNA gen target (ETH10) menggunakan PCR yaitu Mesin Mastercycler gradient eppendorf, ice box, mikropipet P10, P200 dan tipsnya, dan tabung PCR $0.2 \mathrm{~mL}$ steril, selanjutnya satu set alat elektroforesis (Bio-Rad PowerPac Basic) mengandung power supply dan tangki elektroforesis, dan UV Transimulator.

Bahan yang dibutuhkan adalah produk PCR Ladder (marker), bubuk agarosa, TBE 1x, Loading dye, EtBr, DNA template, PCR Dream Taq Mastermix, Primer F (10 pmol/ $\mu \mathrm{l})$, Primer R (10 pmol/ $\mu \mathrm{l})$, DDW, hand gloves, Larutan sampel DNA, tisu KIMWIPE, tisu handuk, $\mathrm{NaCl}$ pekat, alkohol 96\% dingin dan alkohol 70\%, Sampel Darah sapi Pasundan, RCLB pH 7,2, TBS pH 7,4, dan Reagen Buffer TE, dan Reagen Proteinase K solutio.

\section{Koleksi Sampel Darah}

Sampel darah sebanyak $3 \mathrm{~mL}$ dikoleksi dari 3 ekor sapi melalui Vena Caudalis dengan cara jarum 21 G dipasang kedalam Holder kemudian dimasukkan dalam vacutainer tube yang berisi K3EDTA sebagai zat anti koagulan, masing-masing sampel darah diberi label.

\section{Isolasi DNA}

Isolasi DNA dari darah padapenelitian ini menggunakan metode "Garam Pekat" oleh Montgomery and Sise (1990). Tahapannya dengan cara koleksi WBC (White Blood Cell) dari sampel darah yang telah dikoleksi, kemudian dilakukan removal protein dan terakhir dilakukan presipitasi DNA.

\section{Kuantifikasi DNA}

Kuantifikasi DNA bertujuan untuk mengetahui tingkat kemurnian DNA dan konsentrasinya $A^{\circ} 260 / A^{\circ} 280$ dari proses isolasi menggunakan alat Spektrofotometer UV-Vis.

\section{Amplifikasi Marka target (ETH10)} menggunakan metode PCR

Sampel yang telah di kuantifikasi, yaitu nomer kode 626, 602, dan 619 kemudian disiapkan untuk diidentifikasi. Komponen PCR dengan total $10 \mu \mathrm{l}$ (5 $\mu \mathrm{l}$ PCR Mix Tag Green Polymerase, $2 \mu \mathrm{l}$ DDW, $1 \mu$ l Primer F (Forward), $1 \mu \mathrm{l}$ Primer R (Reverse) dengan Runutan basa (sekuen) primer F/R:5'GTTCAGGACTGGCCCTGCTAACA3' / 5'-CCTCCAGCCCACTTTCTCTTCTC-3', dan $1 \mu$ I DNA) dalam mikrotube PCR untuk setiap masing-masing sampel DNA uji. Sampel kemudian dilakukan amplifikasi dengan program running PreDenaturasi $\left(94^{\circ} \mathrm{C}\right.$ selama 2 menit), Denaturasi $\left(94^{\circ} \mathrm{C}\right.$ selama 30 detik), Annealing $\left(55^{\circ} \mathrm{C}\right.$ selama 45 detik), Extension $\left(72^{\circ} \mathrm{C}\right.$ selama 45 detik), Finalextension $\left(72^{\circ} \mathrm{C}\right.$ selama 10 
menit), dalam mesin thermalcycler Eppendorf yang telah terprogram 35 siklus.

\section{Elektroforesis Produk PCR dan Visualisasi DNA}

Elektroforesis dan Visualisai dilakukan dengan gel agarosa. Sebanyak $5 \mu$ DNA ladder hasil amplifikasi metode PCR (Produk PCR) dihomogenkan dengan loading dye sebanyak $1 \mu \mathrm{l}$ (total $6 \mu \mathrm{l}$ ) dalam parafilm, kemudian dimasukkan kedalam sumuran gel agarosa, selanjutnya di elektroforesis (di Running selama 1 jam, dengan besar arus 100 volt).

Visualisai DNA dilakukan dengan cara merendam gel agarosa hasil elektroforesis dalam campuran EtBr dan TBE selama 1 jam kemudian diletakkan gel diatas UV Transiluminator.

\section{Teknik Analisis Data}

Hasil dianalisis dengan melakukan pengamatan secara lansung band/Pita yang tervisualisasi visualisai dalam UV Transiluminator.

\section{HASIL DAN PEMBAHASAN}

Hasil kuantifikasi yang dilakukan tersaji dalam tabel 1 berikut :

Tabel 1 Hasil Kuantifikasi DNA sapi pada OD $260 / 280$

\begin{tabular}{cccc}
\hline No & Kode Sampel & Konsentrasi DNA & Kemuminian \\
\hline 1 & 626 & $162,5 \mathrm{ng} / \mu \mathrm{l}$ & 1,709 \\
2 & 602 & $142,5 \mathrm{ng} / \mathrm{ll}$ & 1,700 \\
3 & 619 & $44,1 \mathrm{ng} / \mu \mathrm{l}$ & 1,764 \\
\hline & Rerata sd & $116,37 \pm 63,37$ & $1,72 \pm 0,035$ \\
\hline
\end{tabular}

Hasil kuantifikasi pada Tabel 1 menunjukkan ketiga sampel memenuhi untuk dilakukan proses tahap selanjutnya yaitu dilakukan amplifikasi marka target dengan metode PCR, karena untuk dapat dilakukan amplifikasi, konsentrasi minimal sampel adalah $25 \mathrm{ng} / \mu \mathrm{l}$. Sedangkan untuk kemurnian DNA menurut Sambrook et al. (1989), sampel DNA dikatakan murni jika nilai absorbansi 260 terhadap nilai absorbansi 280 berada diantara 1,75-2,0. Jika rasio tersebut $<1,75$ maka DNA dikatakan masih mengandung protein. Sedangkan jika rasionya $>2,0$ maka DNA masih mengandung RNA. Dari ketiga sampel yang diuji yang menunjukkan DNA murni tanpa kontaminasi protein atau RNA adalah kode sampel 619 dengan kemurnian yaitu 1,764. Sedangkan pada kedua sampel yang lain (kode 626 dan 602) kemurniannya masih $<1,75$ artinya masih mengandung protein dalam DNA uji, ini bisa dikarenakan kurang banyak dalam penambahan Proteinase-K, karena jika dihubungkan dengan konsentrasi dari dua sampel pada kode ini menunjukkan konsentrasinya tinggi, 
sehingga tentu membutuhkan lebih banyak Proteinase-K untuk melisiskan protein.

Hasil visualisasi (Gambar 1) menunjukan bahwa pada penelitian ini telah berhasil teramplifikasi marka ETH10 sampel sapi Pasundan dengan

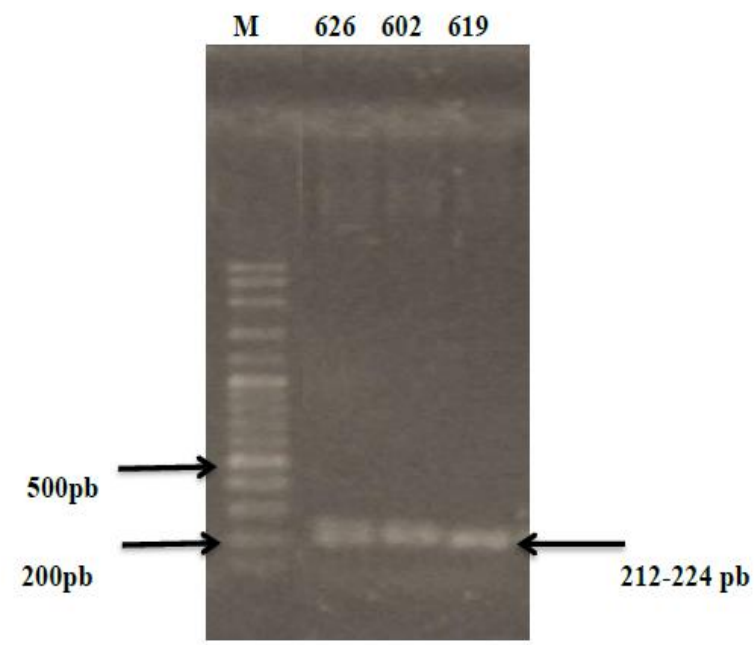

panjang 212-224 pb. Hal ini sesuai dengan penelitian Amstrong et al. (2006); Sodhi et al. (2006); dan Upreti et al. (2012). Untuk kode sampel 626 memiliki pita yang sangat tebal, ini disebabkan karena konsentrasi DNA tertinggi dibanding yang lain (Tabel 1).

Gambar1. Hasil elektroforesis marka ETH10 (212-224pb) pada sapi Pasundan (Dokumentasi pribadi, 2017).

Hasil penelitian konfirmasi marka ETH10 pada sapi Pasundan ini menunjukkan telah berhasil terkofirmasi marka ETH10 pada sapi Pasundan, untuk ini maka memungkinkan untuk melakukan kegiatan pemuliaan terhadap sapi Pasundan agar kekayaan ternak lokal dapat dipertahankan sebab marka ETH10 telah diketahui terlibat dalam signaling GH (Growth Hormone), dimana berperan dalam mengatur pertumbuhan tulang postnatal dan otot serta metabolisme lemak pada mamalia juga diketahui sangat terkait dengan marbling pada sapi.

Anjuran pemuliaan ternak juga terdapat dalam alquran sebab disana dapat kita ketahui tanda-tanda kebesaran Allah agar menjadikan manusia selalu bersyukur, seperti yang terdapat pada :

QS. An-Nahl ayat 66

"Dan sesungguhnya pada binatang ternak itu benar-benar terdapat pelajaran bagi kamu. Kami memberimu minum dari pada apa yang berada dalam perutnya (berupa) susu yang bersih antara tahi dan darah, yang mudah ditelan bagi orangorang yang meminumnya"

QS. Al Mukminun ayat 21

"Dan sesungguhnya pada binatang ternak itu terdapat pelajaran yang penting bagi kamu. Kami memberi minum kamu dari air susu yang ada di dalam perutnya,dan (juga) pada binatang itu terdapat manfaat yang banyak untuk kamu, dan sebagian dari padanya kamu makan". (QS. Al Mukminun: 21) 
Ayat tersebut memberikan bimbingan kepada manusia untuk melakukan ternak sapi danmendukung kegiatan pemuliaan ternak sapi agar dapat dijadikakan manfaat dalam kehidupan manusia sehari-hari, baik dari dagingnya, susunya, kulitnya, dan lain sebagainya.

\section{KESIMPULAN}

Berdasarkan hasil penelitian yang telah dilakukan, disimpulkan beberapa hal sebagai berikut. Ketiga sampel DNA sapi Pasundan telah berhasil diisolasi sebanyak kira-kira 3mL. Diperoleh hasil kuantifikasi dengan rata-rata konsentrasi DNA sebesar 116,37 $\pm 63,37 \mathrm{ng} / \mu \mathrm{l}$ dan kemurnian DNA sebesar 1,72 $\pm 0,035$. Marka ETH10 telah berhasil terkonfirmasi dengan ukuan 212-224 panjang basa pada sapi Pasundan.

Saran Perlu dilakukan sekuensing untuk memastikan sekuen ETH10 yang telah teramplifikasi untuk penelitian selanjutnya dalam keragaram genetik pada sapi Pasundan.

\section{DAFTAR PUSTAKA}

Barendse, W.J. 2002. DNA markers for meat tenderness. International patent application PCT/AU02/00122. [International patent publication WO 02/064820 A1].
Ciampolini, R.K., Moazami, G.D., C, Vaiman., E, Dillman., J.L. Mazzanti., H, Foulley., Levezeil, and D, Cianci. 1995. Individual multilocus genotypes using microsatellite polymorphisms to permit the analysis of the genetic variability within and between Italian beef cattle breeds. Journal of Animal Science. 73: 3259-3268.

Fatchiyah, Sri Widyarti, Estri Laras Arumningtyas, Sofi Permana. 2012. Petunjuk Praktikum Teknis Analisis Biologi Molekuler. Malang. Jurusan Biologi Fakultas MIPA, Universitas Brawijaya.

Johari, S., E. Kurnianto, Sutopo, dan S. Aminah. 2007. Keragaman Protein Darah Sebagai Parameter Biogenetik pada Sapi Jawa. Journal Indonesian Tropical Agriculture. 32 (2): 2-7.

Kim, J. J., F. Fernir, J. Savell, and J. F. Taylor. 2003. Detection of quantitative trait loci for growth and beef carcass fatness traits in a cross between Bos taurus (Angus) and Bos indicus (Brahman) cattle. Journal of Animal Sciece. 81:1933-1942.

Maskur, Muladno, dan B. Tappa. 2007. Identifikasi Genetik Menggunakan Marker Mikrosatelit dan Hubungannya dengan Sifat Kuantitatif pada Sapi. Jurnal Peternakan. 30 (3) : 3-6.

Sambrook, J., E.F. Fritsch, T. Maniatis. 1989. Molecular Cloning Laboratory Manual 3rd Ed. Cold Spring Harbour Lab. Press. New York.

Sellner E.M., Kim J.W., McClure M.C., Taylor K.H., Schnabel R.D. \& Taylor J.F. (2007) Board-invited review: applications of genomic information 
in livestock. Journal of Animal Science 85, 3148-58.

Sodhi M, Mukesh M, Prakash B, Ahlawat SPS, Sobti RC. 2006 . Microsatellite DNA typing for assessment of genetic variability in Tharparkar breed of Indian zebu ( Bos indicus ) cattle, a major breed of Rajasthan. J Genet. $85: 165-170$.

Sunnucks, P., 2000. Efficient genetic markers for population biology. Trends in Ecology \& Evolution. 15 (5): 199-203.

Upreti, Mona, Farah Naz Faridi, S. Maherchandani, B.N. Shingi, S.K. Kshyap. 2012. Genetic Diversity Study Of Indegenous Cattle (Gir And Kankrej) Population Of Rajasthan Using Microsatellite Markers. Journal of Biotechnology.19: 97.

Zhu, T., E. L. K. Goh, R. Graichen, L. Ling, and P. E. Lobie. 2001. Signal transduction via the growth hormone receptor. Cell. Signal. 13:599-616. 